\title{
Transcultural adaptation of the Injustice Experience Questionnaire into Brazilian Portuguese
}

\author{
Adaptação transcultural do Injustice Experience Questionnaire para o português do Brasil \\ Daiane Lopes dos Santos ${ }^{1}$, Marcella de Souza Marins ${ }^{1}$, Leandro Calazans Nogueira², Renato S. Almeida ${ }^{3}$, Michael John L. \\ Sullivan ${ }^{4}$, Felipe Reis ${ }^{5}$
}

DOI 10.5935/2595-0118.20180057

\section{ABSTRACT}

BACKGROUND AND OBJECTIVES: It has been proposed that some individuals with musculoskeletal pain may perceive themselves as victims of injustice. Perception of injustice can have a significant impact on several pain-related outcomes, major depressive symptoms, disabilities, and absenteeism. The objective of this study consisted of a transcultural adaptation of the original instrument in English, Injustice Experience Questionnaire into a final version to be used in Brazil.

METHODS: The whole translation process consisted of translation, back-translation and the review by a committee of experts. The pre-test was applied to 90 participants (41 participants with chronic musculoskeletal pain). For the psychometric analysis, the translated version was applied to 120 participants with chronic musculoskeletal pain. The internal consistency was verified by the Cronbach's alpha coefficient, and the construct validity was analyzed using factorial exploratory analysis.

RESULTS: After the conclusion of the pre-test, there were no difficulties in understanding the translated questionnaire by more than $20 \%$ of the sample. The Cronbach alpha calculation for the 12 items of the Injustice Experience Questionnaire/PortBR was 0.86 [CI $(95 \%)=0.83$ to $0.90 ; \mathrm{p}<0.001$ ].

CONCLUSION: The questionnaire's Portuguese version proved to be easily understandable showing good semantic validation. Nevertheless, further studies should address other psychometric characteristics of this instrument.

Keywords: Chronic pain, Mood disorders, Pain measurement, Psychometrics, Questionnaire, Translations.

1. Instituto Federal de Educaçáo, Ciência e Tecnologia do Rio de Janeiro, Rio de Janeiro, RJ, Brasil. 2. Instituto Federal de Educaçáo, Ciência e Tecnologia do Rio de Janeiro, Centro Universitário Augusto Motta, Programa de Pós-Graduação em Ciências da Reabilitação, Rio de Janeiro, RJ, Brasil

3. Centro Universitário Serra dos Órgãos, Centro Universitário Augusto Motta, Programa de Pós-Graduação em Ciências da Reabilitaçâo, Rio de Janeiro, RJ, Brasil.

4. McGill University, Departamento de Psicologia, Montreal, Canada.

5. Instituto Federal de Educação, Ciência e Tecnologia do Rio de Janeiro, Universidade Federal do Rio de Janeiro, Rio de Janeiro, RJ, Brasil.

Submitted on April 24, 2017.

Accepted for publication on August 30, 2018

Conflict of interests: none - Sponsoring sources: none.

Correspondence to:

Campus Realengo - Rua Carlos Wenceslau, 343 - Realengo

21715-000 Rio de Janeiro, RJ, Brasil.

E-mail: felipe.reis@ifrj.edu.br

(C) Sociedade Brasileira para o Estudo da Dor

\section{RESUMO}

JUSTIFICATIVA E OBJETIVOS: Tem sido proposto que algumas pessoas com dor musculoesquelética podem desenvolver um sentimento de injustiça. A percepção da injustiça pode ter um impacto significativo em uma série de desfechos relacionados à dor, sintomas depressivos maiores, incapacidades e absenteísmo. $\mathrm{O}$ objetivo deste estudo consistiu em uma adaptação transcultural do instrumento original em inglês do Injustice Experience Questionnaire para uma versão final a ser utilizada no Brasil.

MÉTODOS: Todo o processo consistiu em tradução, retrotradução e revisão pelo comitê de especialista. $\mathrm{O}$ pré-teste foi aplicado a 90 participantes (41 participantes com dor crônica musculoesquelética). Para a análise psicométrica, a versão traduzida foi aplicada a 120 participantes com dor crônica musculoesquelética. A consistência interna foi verificada pelo coeficiente alfa de Cronbach e a validade do construto foi analisada por meio de análise exploratória fatorial.

RESULTADOS: Após a conclusão do pré-teste, não houve dificuldades em entender cada item do questionário traduzido por mais de $20 \%$ da amostra. O cálculo alfa de Cronbach para os 12 itens do Injustice Experience Questionnaire/Port-BR foi de 0,86 [IC $(95 \%)=0,83$ a 0,$90 ; \mathrm{p}<0,001]$.

CONCLUSÃO: A versão em português do questionário mostrou-se facilmente compreensível com boa validação semântica. No entanto, estudos adicionais devem abordar outras características psicométricas desse instrumento.

Descritores: Distúrbios do humor, Dor crônica, Mensuração da dor, Psicometria, Questionário, Tradução.

\section{INTRODUCTION}

Chronic pain has been considered a public health problem ${ }^{1}$. The evidence in the literature highlights that cognitive and emotional factors, such as negative thoughts, fear related to pain, anxiety, and depression may contribute to chronification ${ }^{2-8}$.

Among the cognitive and emotional factors, the perception of injustice is characterized when an individual is exposed to situations where there is a violation of basic human rights, the transgression of status or position, or loss of equity ${ }^{9-11}$. The experience of unnecessary suffering as a result of the actions of others and the individual evaluations of irreparable losses can also give rise to perceptions of injustice ${ }^{12}$. The experience of injustice is a complex construct, characterized by the evaluation of elements of the severity of loss, feeling of guilt, sense of injustice and irreparability of loss. The 
experience of injustice can be considered as a source of stress responses and negative feelings for people with chronic pain ${ }^{2-8}$.

The Injustice Experience Questionnaire (IEQ) developed by Sullivan et al. ${ }^{2}$ to evaluate the experience of injustice seeks to identify the interpretation of personal losses as serious and irreparable and the transfer the guilt of their suffering to another person ${ }^{2,3}$. Injustice comprises elements of the severity of loss resulting from the injury ("Most people don't understand how severe is my condition"), guilt ("I am suffering because of someone's negligence"), sense of injustice ("It all seems so unfair") and irreparability of loss ("My life will never be the same"). The factorial analysis of the original instrument reveals that the IEQ produces two correlated factors that were classified as severity/ irreparability of loss and guilt/injustice ${ }^{2}$.

People who interpret their current health situation with perceptions of injustice may need a longer recovery period ${ }^{14}$, present insufficient treatment results ${ }^{2,15-17}$, and physical health losses ${ }^{18}$ and as a significant predictor of greater intensity of pain, depression and post-traumatic symptoms after injury ${ }^{19}$.

Considering the influence of the experiences of injustice in the chronification of musculoskeletal pain, and the absence of an instrument to evaluate the experience of injustice in the Brazilian scenario, this study aimed to conduct a process of cross-cultural adaptation of the proposed instrument to the Brazilian context. Also, to present a version of the IEQ for clinical use and future psychometric analyzes in different scenarios. This study may contribute by providing an instrument for evaluating a previously unseen domain in the Brazilian population.

\section{METHODS}

The process of cross-cultural adaptation was carried at the Physical Therapy Service of the Clinic School of the Federal Institute of Science and Technology of Rio de Janeiro (IFRJ), Realengo Campus and the Gaffrée and Guinle University Hospital.

The IEQ consists of 12 items in which the respondent responds using the Likert scale with 5 options: (0) never, (1) rarely, (2) sometimes, (3) often, and (4) all the time. The total score of the instrument refers to the sum of all 12 items indicating that the higher the score, the greater the experience of injustice perceived by the person. The instrument still covers two dimensions called "guilt and injustice" (items 3, 7, 9, 10, 11 and 12) "severity and irreparability of loss" (items 1, 2, 4, 5, 6 and 8) ${ }^{2}$.

After the authors' authorization, the cross-cultural adaptation was composed of the content analysis of the scale by a committee of experts, and a pre-test divided into the following stages: preparation, translation, reconciliation (synthesis), back-translation, back-translation review, harmonization (comparison of the back-translated versions), revised text correction and lastly, the final report ${ }^{20-22}$.

The process of translation into Brazilian Portuguese was performed by two sworn translators, independent and bilingual (T1 and T2). After analysis, the T1 and T2 versions originated the T12 version. The T12 version was back-translated into English by two other bilingual translators (RT1 and RT2). These two translators were not aware of the original version of the questionnaire.
The committee of experts, consisting of two physical therapists, two psychologists, a social worker and all the translators involved in the process performed the revision of the versions (original, T1, T2, T12, RT1, RT2 and RT12). This stage allowed the consolidation of the versions, and the preparation of the pre-final version of IEQ was used to eliminate any item not comprised by more than $20 \%$ of the sample ${ }^{23}$.

The pre-test was applied to subjects with chronic musculoskeletal pain, selected by spontaneous demand, and a control group formed by individuals without musculoskeletal pain. People of both genders participated in the study, with a minimum age of 18 years, with musculoskeletal pain for more than three months, of traumatic origin or not. People with cognitive impairment that could hinder the performance of the research procedures were not considered eligible for the study. The guiding question for this step was, "Did you understand the phrase?" The participant should indicate in a visual scale a minimum value of " 0 " ("I did not understand anything") and the maximum value " 5 " ("I understood perfectly, and I have no doubts"). It was established that the first three values would be considered as indicators of insufficient understanding and, in that case, the phrase should be reviewed by the research team.

This study was approved by the Research Ethics Committee (CAAE: 53993516.8.0000.5268) of the Federal Institute of Rio de Janeiro.

\section{Statistical analysis}

Data were tabulated in a spreadsheet and analyzed with the SPSS Software version 20 for Windows (SPSS Inc., Chicago, Illinois). The sample size calculation followed the Kerlinger ${ }^{24}$ criteria that recommend the inclusion of 10 subjects per item of a scale.

The 12 IEQ items were submitted to the exploratory factor analysis (EFA) via main components, followed by oblique rotation (direct Oblimin) to check the behavior of the items before their respective latent variables (dimensions). The reliability of the instrument was evaluated by analyzing the internal consistency of the items, separately for each dimension. In order to determine the optimum number of factors to be retained in the analysis of the main components and the instrument configuration model, the following criteria were used: (1) Kaiser criterion (retention of factors with eigenvalues greater than 1.0); (2) the "commonality" of the items should be $\geq 0.50$; (3) the capacity to interpret the factorial load (for the item to be retained in a given factor, the load should be $\geq 0.60$ in one factor and $\leq 0.40$ in the other factors). Internal consistency was evaluated using the Cronbach's alpha coefficient, with values above 0.70 for each dimension being desired ${ }^{25}$.

\section{RESULTS}

The study consisted of two stages with a total of 210 participants. Initially, the IEQ was applied to 90 individuals, 49 healthy subjects and 41 with chronic pain, to evaluate the understanding and semantic, idiomatic, cultural and conceptual equivalence. This group consisted of 73 women and 17 men, with a mean age of 24.6 years $(\mathrm{SD}=6.7, \mathrm{xmin}=19, \mathrm{xmax}=51)$ for the healthy group 
and 60.3 years $(S D=12, x \min =23 ; x \max =83)$ for the patients. Regarding education, all healthy participants had an incomplete higher education. In the group of people with musculoskeletal pain, $1(2.4 \%)$ did not have formal education, 18 (43.9\%) had elementary school degree, 15 (36.5\%) had high school degree and $5(12.1 \%)$ incomplete higher education.

The second stage consisted of the psychometric evaluation of 120 volunteers with chronic musculoskeletal pain who had not participated in the initial stage and therefore were unaware of the instrument. Of these participants, 104 (86.7\%) were women, and $16(13.3 \%)$ were men. The mean age was 62.4 years $(\mathrm{SD}=14.3 ; \mathrm{xmin}=20-\mathrm{xmax}=92)$. Regarding formal education level, most participants $52(43.3 \%)$ did not have formal education or had incomplete elementary education, 23 (19.2\%) had incomplete elementary school and high school, 34 (28.3\%) had a high school degree and incomplete higher education and 10 $(8.3 \%)$ a higher education degree. One participant $(0.8 \%)$ did not declare his/her degree of education.

The semantic equivalence process formed similar versions, with minimal differences between translations $\mathrm{T} 1$ and $\mathrm{T} 2$. In back-translation, the RT1 and RT2 versions were quite similar to each other, and to the original version of IEQ. No item had difficulty understanding more than $20 \%$ of the sample. The process of cross-cultural adaptation gave rise to the Brazilian Portuguese version of the IEQ (IEQ/PORT-BR) (Appendix 1). The stages of translation and validation of the content are shown in table 1.
The inspection of the correlation matrix revealed the presence of several coefficients with values above 0.3 . The measure of the adequacy of the Kaiser-Meyer-Oklin (KMO) sample was 0.86, and the Barlett sphericity test reached statistical significance, supporting the factor correlation matrix $\left(\mathrm{X}^{2}=488.8 ; \mathrm{p}<0.001\right)$. The analysis of main components revealed the presence of three components with their own values greater than 1, explaining $41.5 \%, 9.2 \%$ and $8.4 \%$ of the variance, respectively.

The analysis of the result after Oblimin rotation showed a model with three factors (Table 2), that explains $50.8 \%$ of the variance - with Dimension 1 (Severity and Irreparability) accounting for $41.5 \%$, and Dimension 2 (Guilt and Injustice) accounting for $9.2 \%$. Within the structural model presented, the first dimension, severity/irreparability of loss accounted for $73.5 \%$ of the total variance, and the second dimension, guilt/injustice, for $26.1 \%$ of the total variance. The analysis suggests that questions Q9 ("Nothing will ever make up for all that I have gone through") and Q11 ("I am troubled by fears that I may never achieve my dreams") carry both dimensions. In addition, questions Q8 ("I worry that my conditions not being taken seriously") and Q3 ("I am suffering because of someone else's negligence") carried a third dimension that we believe is related to the perception of negligence.

The Cronbach's alpha calculation for the 12 IEQ-Portuguese items was 0.86 [CI $(95 \%)=0.83-0.90 ; \mathrm{p}<0.001)$. The correlation coefficients (r) Item-total ranged from 0.28 to 0.71 (Table 3).

Table 1. Presentation of the original, translated (T12), back-translated and final versions

\begin{tabular}{|c|c|c|c|c|}
\hline Item & Original version & Translation (T12) & Back-translation (RT12) & Final Version \\
\hline 1 & $\begin{array}{l}\text { Most people don't understand } \\
\text { how severe my condition is. }\end{array}$ & $\begin{array}{l}\text { A maioria das pessoas não en- } \\
\text { tende como meu problema de } \\
\text { saúde é sério. }\end{array}$ & $\begin{array}{l}\text { Most people do not unders- } \\
\text { tand how serious my health } \\
\text { problem is. }\end{array}$ & $\begin{array}{l}\text { A maioria das pessoas não en- } \\
\text { tende o quanto a minha lesão é } \\
\text { séria. }\end{array}$ \\
\hline 2 & My life will never be the same. & $\begin{array}{l}\text { A minha vida nunca será a } \\
\text { mesma. }\end{array}$ & My life will never be the same. & $\begin{array}{l}\text { Minha vida nunca mais será a } \\
\text { mesma. }\end{array}$ \\
\hline 3 & $\begin{array}{l}\text { I am suffering because of so- } \\
\text { meone else's negligence. }\end{array}$ & $\begin{array}{l}\text { Estou sofrendo por causa da } \\
\text { negligência de outra pessoa. }\end{array}$ & $\begin{array}{l}\text { I am suffering because of so- } \\
\text { meone else's negligence. }\end{array}$ & $\begin{array}{l}\text { Estou sofrendo por causa da } \\
\text { falta de cuidado de outra pes- } \\
\text { soa. }\end{array}$ \\
\hline 4 & $\begin{array}{l}\text { No one should have to live this } \\
\text { way. }\end{array}$ & $\begin{array}{l}\text { Ninguém deveria ter que viver } \\
\text { desta maneira. }\end{array}$ & $\begin{array}{l}\text { Nobody should have to live that } \\
\text { way. }\end{array}$ & $\begin{array}{l}\text { Ninguém deveria ter que viver } \\
\text { dessa maneira. }\end{array}$ \\
\hline 5 & I just want to have my life back. & $\begin{array}{l}\text { Eu só quero ter a minha vida de } \\
\text { volta. }\end{array}$ & I just want to have my life back. & $\begin{array}{l}\text { Eu só quero ter minha vida de } \\
\text { volta. }\end{array}$ \\
\hline 6 & $\begin{array}{l}\text { I feel that this has affected me in } \\
\text { a permanent way. }\end{array}$ & $\begin{array}{l}\text { Eu sinto que isto me afetou de } \\
\text { maneira permanente. }\end{array}$ & $\begin{array}{l}\text { I think it affected me in a per- } \\
\text { manent way. }\end{array}$ & $\begin{array}{l}\text { Eu percebo que isso me afetou } \\
\text { de uma maneira permanente. }\end{array}$ \\
\hline 7 & It all seems so unfair. & Isso tudo parece tão injusto. & It all seems so unfair & Isso tudo parece tão injusto. \\
\hline 8 & $\begin{array}{l}\text { I worry that my conditions not } \\
\text { being taken seriously. }\end{array}$ & $\begin{array}{l}\text { Eu tenho medo de que meu } \\
\text { problema de saúde não seja le- } \\
\text { vado a sério. }\end{array}$ & $\begin{array}{l}\text { I'm afraid that my health pro- } \\
\text { blem is not taken seriously. }\end{array}$ & $\begin{array}{l}\text { Estou preocupado que meu } \\
\text { problema não esteja sendo le- } \\
\text { vado a sério. }\end{array}$ \\
\hline 9 & $\begin{array}{l}\text { Nothing will ever make up for all } \\
\text { that I have gone through. }\end{array}$ & $\begin{array}{l}\text { Nada jamais vai compensar } \\
\text { tudo que eu passei. }\end{array}$ & $\begin{array}{l}\text { Nothing will make up for all that } \\
\text { I have gone through. }\end{array}$ & $\begin{array}{l}\text { Nada vai compensar tudo que } \\
\text { eu passei. }\end{array}$ \\
\hline 10 & $\begin{array}{l}\text { I feel as if I have been robbed of } \\
\text { something very precious. }\end{array}$ & $\begin{array}{l}\text { Sinto como se tivessem me } \\
\text { roubado algo muito valioso. }\end{array}$ & $\begin{array}{l}\text { I feel like someone has stolen } \\
\text { me something very valuable }\end{array}$ & $\begin{array}{l}\text { Sinto como se tivessem rouba- } \\
\text { do algo muito precioso de mim. }\end{array}$ \\
\hline 11 & $\begin{array}{l}\text { I am troubled by fears that I may } \\
\text { never achieve my dreams. }\end{array}$ & $\begin{array}{l}\text { Eu estou com medo de que eu } \\
\text { nunca possa alcançar os meus } \\
\text { sonhos. }\end{array}$ & $\begin{array}{l}\text { I'm worried that I might never } \\
\text { realize again my dreams }\end{array}$ & $\begin{array}{l}\text { Estou preocupado em nunca } \\
\text { mais poder alcançar os meus } \\
\text { sonhos. }\end{array}$ \\
\hline 12 & $\begin{array}{l}\text { I can't believe this has happened } \\
\text { to me. }\end{array}$ & $\begin{array}{l}\text { Eu não posso acreditar que } \\
\text { isso aconteceu comigo. }\end{array}$ & $\begin{array}{l}\text { I can not believe this happened } \\
\text { to me. }\end{array}$ & $\begin{array}{l}\text { Eu não posso acreditar que isso } \\
\text { tenha acontecido comigo. }\end{array}$ \\
\hline
\end{tabular}


Table 2. Analysis of the main components of the Injustice Experience Questionnaire in Portuguese

\begin{tabular}{|c|c|c|c|c|}
\hline Item & & Factor 1 & Factor 2 & Factor 3 \\
\hline Q7 & It all seems so unfair & 0.71 & 0.07 & 0.26 \\
\hline Q6 & I feel that this has affected me in a permanent way & 0.77 & 0.17 & 0.11 \\
\hline Q10 & I feel as if I have been robbed of something very precious & 0.56 & 0.36 & 0.36 \\
\hline Q4 & No one should have to live this way & 0.71 & 0.18 & 0.08 \\
\hline Q2 & My life will never be the same & 0.18 & 0.78 & 0.10 \\
\hline Q3 & I am suffering because of someone else's negligence & 0.03 & 0.03 & 0.85 \\
\hline Q8 & I worry that my conditions not being taken seriously & 0.33 & 0.26 & 0.54 \\
\hline Q9 & Nothing will ever make up for all that I have gone through & $0.45^{\star}$ & $0.53^{*}$ & 0.25 \\
\hline
\end{tabular}

Values equal to or greater than 0.50 are indicated in bold. * Items with high loads by more than one factor.

Table 3. Correlation coefficients ( $r$ ) Total-item and Cronbach alpha by factors

\begin{tabular}{llcr}
\hline Item & & $\begin{array}{c}\text { (r) } \\
\text { Total item }\end{array}$ & $\begin{array}{c}\text { Cronbach alpha } \\
\text { if the item is deleted }\end{array}$ \\
\hline Q1 & Most people don't understand how severe my condition is & 0.50 & 0.86 \\
Q2 & My life will never be the same & 0.45 & 0.28 \\
Q3 & I am suffering because of someone else's negligence & 0.52 \\
Q4 & No one should have to live this way & 0.56 & 0.87 \\
Q5 & I just want to have my life back & 0.63 & 0.86 \\
Q6 & I feel that this has affected me in a permanent way & 0.50 & 0.85 \\
Q7 & It all seems so unfair & 0.51 \\
Q8 & I worry that my conditions not being taken seriously & 0.65 \\
Q9 & Nothing will ever make up for all that I have gone through & 0.68 \\
Q10 & I feel as if I have been robbed of something very precious & 0.85 \\
Q11 & I am troubled by fears that I may never achieve my dreams & 0.62 \\
Q12 & I can't believe this has happened to me & 0.71 \\
\hline
\end{tabular}

\section{DISCUSSION}

The IEQ/PORT-BR is the first instrument that has been translated into Portuguese to identify the experience of injustice. The original version developed by Sullivan et al. ${ }^{2}$ was translated and validated for Spanish ${ }^{26}$ and Danish ${ }^{27}$. The IEQ/PORT-BR showed high internal consistency as observed in the original study $^{2}$ and in the Spanish version ${ }^{26}$.

In the factorial analysis performed by Sullivan et al. ${ }^{2}$ and Rodero et al. ${ }^{26}$, the results were similar considering the first component evaluated (severity/irreparability of loss) explaining $54 \%$ of the total variance and the second component (fault/injustice) $9 \%$ of the total variance. In this study, there was no consistency to consider the IEQ/PORT-BR containing two dimensions, since Q3 ("I am suffering because of someone else's negligence") and Q8 ("I worry that my conditions not being taken seriously") questions lead to a third dimension. It is possible that these two questions did not achieve semantic correlation to fit either domain. It is possible that the two questions indicate a third factor for the Portuguese version that would be related to the perception of negligence. Yet, Q9 ("Nothing will ever make up for all that I have gone through") and Q11 ("I am troubled by fears that I may never achieve my dreams") carried both factors. It is possible that the semantics of these questions did not allow a greater adherence to one of the dimensions in the sample studied. This finding points to an inconsistent behavior of this item within the configurable structure proposed by this study. Therefore, future studies are necessary to clarify the real contribution of the item within the model proposed by this study ${ }^{28}$.

The differences observed in the analyzes may be related to the characteristics of the sample of this study that was composed by people with chronic pain and diagnosis of musculoskeletal disorders such as low back pain, cervical pain, knee osteoarthritis among others. In the study by Sullivan et $\mathrm{al}^{2}$, the participants had suffered injuries at work, and the study by Rodero et al. ${ }^{26}$ included people with a diagnosis of fibromyalgia.

Another factor that may explain the differences found when compared to the studies of Sullivan et al. ${ }^{2}$ and Rodero et al. ${ }^{26}$ is the sample size. Although the study adhered to Kerlinger ${ }^{24}$ cri- $^{2}$ 
teria that recommended 10 subjects for each item of the instrument, and the value obtained in the KMO test $(0.86)$ that when near 1 indicates that the factorial analysis method is perfectly adequate for the treatment of data, it is possible that a larger sample might reflect differences in the results of the component analysis. In the pre-test phase, differences in mean age and education did not compromise the understanding of the questions. This characteristic allows inferring that the questionnaire can be applied at different ages and education levels without difficulties in the interpretation of the instrument. In addition, the application of the IEQ/PORT-BR was adequate for clinical practice with regard to the ability to understand, the duration of application ranging from 5 to 10 minutes, and to the possibility of being self-applied.

The availability of the IEQ/PORT-BR can provide new information related to the influence of the experience of injustice in people with musculoskeletal pain in Brazil. The perception of injustice seems to be an important factor influencing the pain experience. In a study by Margiotta et al. ${ }^{29}, 33 \%$ presented a high score in the IEQ, with a strong correlation with pain catastrophizing. The study by van Leeuwen et al..$^{30}$ demonstrated that perceived injustice was associated with both function limitation and pain intensity. Yakobov et al. ${ }^{8}$, in a prospective study composed of patients after knee arthroplasty, found that perceived injustice contributed significantly to predict the variance of postoperative pain severity.

The results of this study can be considered initial with regard to the psychometric analysis process, being necessary to study other populations, as well as other statistical procedures such as confirmatory factorial analysis, analyzes of internal consistency and concurrent validation in different populations.

\section{CONCLUSION}

The Injustice Experience Questionnaire obtained in the process of cross-cultural adaptation to the Portuguese language proved to be adequate for clinical application and investigation of the experience of injustice in the Brazilian population.

Appendix 1. Injustice Experience Questionnaire for Portuguese Brazil

Name Age Gender Date

When injuries occur, they can have a profound impact on our lives. This scale was developed to evaluate how your injury has affected your life.

The following are 12 statements that describe different thoughts and feelings that you may have when you think about your injury. Indicate how often you have these feelings and thoughts when you think about your injury.

$0=$ never $\quad 1=$ rarely $2=$ sometimes $3=$ often $\quad 4=$ all the time

$1 \square$ Most people don't understand how severe my condition is

$2 \square$ My life will never be the same

$3 \square$ I am suffering because of someone else's negligence

$4 \quad \square \quad$ No one should have to live this way

$5 \square$ I just want to have my life back

$6 \square$ I feel that this has affected me in a permanent way

$7 \quad \square \quad$ It all seems so unfair

$8 \square$ I worry that my conditions not being taken seriously

$9 \square$ Nothing will ever make up for all that I have gone through

$10 \square$ I feel as if I have been robbed of something very precious

$11 \square$ I am troubled by fears that I may never achieve my dreams

$12 \square$ I can't believe this has happened to me

\section{REFERENCES}

1. Rice AS, Smith BH, Blyth FM. Pain and the global burden of disease. Pain. 2016;157(4):791-6

2. Sullivan MJ, Adams H, Horan S, Maher D, Boland D, Gross R. The role of perceived injustice in the experience of chronic pain and disability: scale development and validation. J Occup Rehabil. 2008;18(3):249-61.

3. Sullivan MJ, Scott W, Trost Z. Perceived injustice: a risk factor for problematic pain outcomes. Clin J Pain. 2012;28(6):484-8.

4. Scott W, Trost Z, Bernier E, Sullivan MJ. Anger differentially mediates the relationship between perceived injustice and chronic pain outcomes. Pain. 2013;154(9):1691-8.

5. Scott W, Trost Z, Milioto M, Sullivan MJ. Further validation of a measure of injury-related injustice perceptions to identify risk for occupational disability: a prospective study of individuals with whiplash injury. J Occup Rehabil. 2013;23(4):557-65.

6. Scott W, Trost Z, Milioto M, Sullivan MJ. Barriers to change in depressive symptoms after multidisciplinary rehabilitation for whiplash the role of perceived injustice. Clin
J Pain. 2015;31(2):145-51.

7. Kennedy L, Dunstan DA. Confirmatory factor analysis of the Injustice Experience Questionnaire in an Australian compensable population. J Occup Rehabil. 2014;24(3):385-92.

8. Yakobov E, Scott W, Stanish W, Dunbar M, Richardson G, Sullivan M. The role of perceived injustice in the prediction of pain and function after total knee arthroplasty. Pain. 2014;155(10):2040-6.

9. Mohiyeddini C, Schmitt MJ. Sensitivity to befallen injustice and reactions to unfai treatment in a laboratory situation. Soc Justice Res. 1997;10(3):333-53.

10. Fetchenhauer D, Huang X. Justice sensitivity and distributive decisions in experimental games. Person Individ Diff. 2004;36(5):1015-29.

11. Hafer CL, Bègue L. Experimental research on just-world theory: problems, developments and future challenges. Psychol Bull. 2005;131(1):128-67.

12. Miller DT. Disrespect and the experience of injustice. Annu Rev Psychol. 2001;52:527-53.

13. Sullivan MJ, Adams H, Martel MO, Scott W, Wideman T. Catastrophizing and perceived Injustice. Spine. 2011;36(25 Suppl):S244-9. 
14. Gureje O, Von Korff M, Simon GE, Gater R. Persistent pain and well-being: a World Health Organization study in primary care. JAMA. 1998;280(2):147-51.

15. Blyth FM, March LM, Nicholas MK, Cousins MJ. Chronic pain, work performance and litigation. Pain. 2003;103(1):41-7.

16. Ferrari R, Russell AS. Why blame is a factor in recovery from whiplash injury. Med Hypotheses. 2001;56(3):372-5.

17. Turk DC, Okifuji A. Perception of traumatic onset, compensation status, and physical findings: impact on pain severity, emotional distress, and disability in chronic pain patients. J Behav Med. 1996;19(5):435-53.

18. Jackson B, Kubzansky LD, Wright RJ. Linking perceived unfairness to physical health: the perceived unfairness model. Rev Gen Psychol. 2006;10(1):21-40

19. Trost Z, Agtarap S, Scott W, Driver S, Guck A, Roden-Foreman K, et al. Perceived injustice after traumatic injury: associations with pain, psychological distress, and quality of life outcomes 12 months after injury. Rehabil Psychol. 2015;60(3):213-21.

20. Beaton DE, Bombardier C, Guillemin F, Ferraz MB. Guidelines for the process of cross-cultural adaptation of self-report measures. Spine. 2000;25(24):3186-91.

21. Guillemin F, Bombardier C, Beaton D. Cross-cultural adaptation of health-related quality of life measures: literature review and proposed guidelines. J Clin Epidemiol. 1993;46(12):1417-32

22. Wild D, Grove A, Martin M, Eremenco S, McElroy S, Verjee-Lorenz A, et al. Principles of good practice for the translation and cultural adaptation process for PatientReported Outcomes (PRO) Measures: report of the ISPOR Task Force for Translation and Cultural Adaptation. Value Health. 2005;8(2):94-104.
23. Nusbaum L, Natour J, Ferraz MB, Goldenberg J. Translation, adaptation and validation of the Roland-Morris questionnaire--Brazil Roland-Morris. Braz J Med Biol Res. 2001;34(2):203-10

24. Kerlinger FN. Foundations of behavioral research. $3^{\text {rd }}$ ed. New York: Holt, Rinehard and Winston; 1986. 415p.

25. Bastos JL, Celeste RK, Faerstein E, Barros AJ. Racial discrimination and health: a systematic review of scales with a focus on their psychometric properties. Saúde Transform Soc. 2010;2(1):4-16.

26. Rodero B, Luciano JV, Montero-Marín J, Casanueva B, Palacin JC, Gili M, et al. Perceived injustice in fibromyalgia: psychometric characteristics of the Injustice Experience Questionnaire and relationship with pain catastrophising and pain acceptance. J Psychosom Res. 2012;73(2):86-91.

27. la Cour P, Smith AA, Schultz R. Validation of the Danish language Injustice Experience Questionnaire. J Health Psychol. 2015;22(7):825-33.

28. Reichenheim ME, Hökerberg YH, Moraes CL. Assessing construct structural validity of epidemiological measurement tools: a seven-step roadmap. Cad Saude Publica, 2014;30(5):927-39.

29. Margiotta F, Hannigan A, Imran A, Harmon DC. Pain, perceived injustice, and pain catastrophizing in chronic pain patients in Ireland. Pain Pract. 2017;17(5):663-8.

30. van Leeuwen WF, van der Vliet QM, Janssen SJ, Heng M, Ring D, Vranceanu AM Does perceived injustice correlate with pain intensity and disability in orthopaedic trauma patients? Injury. 2016;47(6):1212-6. 